\title{
政 VERSITA
}

ANVIL 29 (1) September 2013

DOI: $10.2478 /$ anv-2013-0005

\section{Hope and the Environment: a Perspective from the Majority World Archbishop Thabo Makgoba*}

\begin{abstract}
This paper considers hope and environment from a majority world perspective. It begins by surveying moves within the Anglican Church to become more environmentally aware, and to integrate environmental concerns into theology and practice. This process began at the Lambeth Conference in 1968 and eventually led to the inclusion of an environmental strand within the Anglican Communion's 'Five Marks of Mission'. The fifth Mark is 'To strive to safeguard the integrity of creation and sustain and renew the life of the earth.' In the 2008 Lambeth Conference a whole section was devoted to the environment.

There follow accounts of environmental work in the Province of Southern Africa. In Niassa Diocese, in northern Mozambique, the mission department has been using Umoja (from the Swahili word for having a common mind) in congregational and community development. It demonstrates holistic mission by deepening faith, building community, and helping with practical challenges. Now the bigger question facing Southern Africa and the majority world is climate change. In South Africa apartheid used to dominate everything and this led to unity in the Church, but after apartheid the country is not faced by one overarching problem, but many. The theology of Charles Mathewes is explored in an attempt to find an adequate Christian response and bring hope to this new context. This then leads on to action in both small practical ways, and in bringing about more fundamental change. Finally, we are reminded that we should not always speak about problems, but also to present a positive vision.
\end{abstract}

\footnotetext{
*20, Bishopscourt Drive, Bishopscourt, Claremont, Cape Town, Western Cape, 7708, South Africa. Email: archpa@anglicanchurchsa.org.za
} 


\section{Introduction}

When I first moved to Bishopscourt in January 2008, I was enchanted by the lustrous purple flowers of the morning glory that trailed across the extensive gardens of this beautiful historic house, the home of Metropolitans since soon after Bishop Robert Gray first arrived in Cape Town in 1848. I was rather taken aback to discover subsequently that it was an invasive alien, illegal to plant or propagate, which spreads rapidly, suffocating all other vegetation. South African law specifies this popular garden plant can only be retained if it does not grow within 30 metres of watercourses - and there is a stream running through the grounds. It had to come out.

By October 2012, as I told a press conference at Bishopscourt, we had already spent over R200,000 (about $£ 15,000$ ) on removing this and other aliens, with assistance from the South African National Biodiversity Institute. The job is far from over. Ahead lies the task of replanting with environmentally appropriate, water-wise alternatives. If only this had been tackled 30 years ago, it would have been far easier and cheaper to uphold good stewardship of God's creation literally in my own backyard. If only we could learn to have the eyes to see what must be done now, rather than having to wait for the benefit of hindsight.

The following day, I left for New Zealand, and the Anglican Consultative Council meeting. Our weed-busting efforts seemed pretty trivial when set alongside the problems of rising sea levels, climate change and environmental degradation, which, Bishop Apimeleki Qiliho of Fiji reported, are leading some residents of Pacific Islands to give serious consideration to resettlement elsewhere. ${ }^{1}$ We also remember how the former President of the Maldives once held an underwater cabinet meeting to highlight the risk of his entire country disappearing beneath the Indian Ocean.

Yet if God is God of all, then all of God's creation matters, and there is no aspect of life in which we can abdicate our responsibility to consider the environmental perspectives. The God who numbers the hairs on our heads and sees a sparrow fall (Matt. 10:29,30), marks the impact of morning glory as surely as he hears the cries of those at risk from ecological disasters.

My source of hope lies here. For we are aligning ourselves with God's mission in God's world, whenever, in our attitudes, words or actions, however small, we 'strive to safeguard the integrity of creation, and sustain and renew the earth', as the last of the Anglican Communion's Five Marks of Mission puts it. And whenever we are aligned with 
God's mission in God's world, we can expect that he will 'prosper the work of our hands' (Deut. 30:9, Ps. 90:17) and that our efforts will not be in vain.

In this article, I want to explore in more detail what it means to live in hope, in relation to the environment, from the perspective of 'the majority world'. In particular, I shall draw on the experiences of the Anglican Church of Southern Africa (ACSA), which includes Angola, Lesotho, Mozambique, Namibia, Swaziland, St Helena and Tristan da Cunha alongside South Africa itself; and as the Chair of the Anglican Communion Environmental Network (ACEN). But let me begin with some historic perspectives.

\section{A Slow Awakening}

It is no secret that the churches, Anglicans included, were slow to grasp how central care for creation is, or should be, to our calling as faithful, obedient, Christians. It has taken a long time to move from a negative interpretation of 'dominion' in Genesis 1 , to the Noahic Covenant of Genesis 9, which upholds the sanctity of life, rainbow-reflected created diversity, and the integrity of creation.

The environment was recorded at the Lambeth Conference only in $1968,{ }^{2}$ when Resolution 7 addressed 'man's (sic) responsible stewardship over nature' and Resolution 8 considered conservation of the seabed from the perspective of avoiding political competition in order that its resources 'be exploited economically or made us of with the aim of safeguarding the interests of mankind'. Resolution 2, Faith in the Living God, 'welcomed ... the prospect of human control of the natural environment' and, placing this alongside 'the increasing extent of human knowledge' and 'the searching enquiry of theologians', called the Church to 'a faith in the living God which is adventurous, expectant, calm, and confident, and to faith in the standards of Christ, who was, and is, and is to come, as the criterion of what is to be welcomed and what is to be resisted in contemporary society.'

By 1978 there had been a shift in understanding what, by the measure of Christ's standards, ought to be resisted, and this included, in the wide-ranging Resolution 1: Today's World, the explicit recognition that:

The resources of our planet are limited; delicate ecological balances can be disturbed by modern technology, or threatened by the toxic effects of human ingenuity. Ways must be found to stop waste, to recycle resources and to monitor and control the manufacture of substances dangerous to life and health. The use of nuclear fuel must 
be subject to the safe and permanent disposal of its toxic by-products. Alternative sources of energy must be harnessed for use.

In Resolution 2: A Response, the Conference called on world leaders 'so to limit the development of nuclear energy that they guard against the proliferation of nuclear weapons, at the same time applying every effort to the development of alternative sources of energy'; on Churches, 'to make provision locally to educate their membership into an understanding of these issues'; and on members, 'to review their life-style and use of the world's resources so that the service and wellbeing of the whole human family comes before the enjoyment of over-indulgent forms of affluence.'

Thus, while some of what we now recognise, with the benefit of hindsight, as the key issues were beginning to surface, they were still very much placed within the context of the Cold War era. In the 1988 Lambeth Conference, the only two references to the environment came in relation to the polluting effects of nuclear weapons testing, and to the interrelationship between economic inequality, social injustice, and the rise of militarism (Resolutions 35 and 40). At least the latter had reference to the need to 'encourage [our people] to see stewardship of God's earth for the care of our neighbours as a necessary part of Christian discipleship and a Christian contribution to citizenship.'

In parallel with the discussions of bishops at Lambeth Conferences, from 1971 clergy and laity had also become formally engaged in global debates of mission and ministry through the Anglican Consultative Council. The second ACC meeting, in Dublin in 1973, also referred to the environment in relation to nuclear weapons, and to the polluting activities of multi-nationals (Resolutions 12 and 18). ${ }^{3}$ But by its seventh meeting, in Singapore in 1987, one resolution (28) was entirely dedicated to the environment, and, inter alia, called on the Inter-Anglican Theological and Doctrinal Commission 'to consider a theological study of the understanding of creation in terms of ecology - the wholeness of creation - for circulation and discussion in the Communion'; and urged 'member Churches to join with governments where possible in providing the leadership and education to provide appropriate balance between development and environmental issues.' It also highlighted the potential link with mission. Meanwhile, from 1984, the ACC had set in motion the process that led to the adoption of the Anglican Communion's 'Five Marks of Mission', the fifth of which is 'To strive to safeguard the integrity of creation and sustain and renew the life of the earth. ${ }^{4}$ 


\section{From the grass roots upwards}

That a more focussed impetus arose from the ACC seems to me no accident. Today, in my experience, it is literally those 'at the grass roots' who often have the greatest sensitivity to environmental perspectives. While the 'Indaba Reflections' reporting the discussions of the 2008 Lambeth Conference devotes an entire section to the Environment, it notes that 'In developing countries and among Indigenous peoples, notably in the Arctic, safeguarding creation is a day to day activity... Indigenous peoples have traditional understandings of the earth as a gift of the Creator and of their relationships to it and its creatures being one of interconnectedness and responsible caring. The Indigenous peoples have reminded us that we are not aliens in a wilderness to be conquered, but integral parts of the created order, as are plants and animals, which are to be cherished and nurtured.. ${ }^{5}$ Much the same can be said of those others who live most closely to their physical environment.

Within my own Province, the poorest and most rural Dioceses have been among the first to incorporate care for creation in their everyday life, and to integrate it holistically within teaching the Christian faith. One example from Lesotho was the decision that all baptism and confirmation candidates (or their families) plant a tree at their home, church, or village. These are then seen as a symbol of faith, to be nurtured in the years ahead as they nurture their Christian commitment. This is increasingly becoming a very visible sign of witness within the local community, where deforestation and soil erosion are significant challenges. Another issue that has directed attention to 'green' practices has been the devastatingly high rates of HIV and AIDS in Southern Africa. These are now beginning to fall, thanks be to God - and thanks also to the increasingly widespread use of anti-retroviral drugs. But these medicines need to be taken with food, prompting many churches to spearhead the introduction of community vegetable gardens, which have also become focuses for teaching around creation care.

\section{Umoja - sharing the mind of Christ}

Another Diocese where there has been a major focus on the environment is Niassa, in the northern half of Mozambique. The lessons they have been learning deserve far wider knowledge and adoption. Much of the Diocese is very remote from Mozambique's capital, Maputo, in terms of both geography and infrastructure, and the great majority of the population is very poor. For some eight years the Diocesan Mission Department has been using the principles of Umoja in congregational and community development. This is an 
incultured form of Appreciative Inquiry, named from the Swahili word for having a common mind. It very much encapsulates the concept of St Paul's exhortation to the Philippians when he says,

If then there is any encouragement in Christ, any consolation from love, any sharing in the Spirit, any compassion and sympathy, make my joy complete: be of the same mind, having the same love, being in full accord and of one mind. Do nothing from selfish ambition or conceit, but in humility regard others as better than yourselves. Let each of you look not to your own interests, but to the interests of others. Let the same mind be in you that was in Christ Jesus ... (Phil. 2:1-5).

At the heart of Umoja is the conviction that the gospel of Jesus Christ is offered to everyone alike, embracing individuals and their communities, in every aspect of human existence. This gospel is literally good news to the poor (Luke 4:18) and his promise of abundant life for all (John 10:10). Further, we are best enabled to grow into receiving God's promises of newness of life when everyone is enabled to contribute to discerning and following God's call 'for the common good', through the Spirit's leading (1 Cor. 12:7). This shows the church acting as the body of Christ, The church does not impose from a central hierarchy, but rather empowers not merely local clergy and their key lay leaders but the entire laos, the whole people of God, to respond to his good purposes for them. This is the best way to further the genuine interests of all, as St Paul wrote to the Philippians. (If you want to know more about Umoja, Tearfund has produced some excellent resources). ${ }^{6}$

The Diocese of Niassa has voluntary groups called Equipa da Vida, Teams of Life, and adeptos or cheerleaders, the diocesan fieldworkers, who have been sharing this methodology in communities. It is proving remarkably effective, and illustrates the true nature of holistic mission: in spreading and deepening faith; in community building; and in helping people address the most fundamental challenges of life which they face. According to the UN's Food and Agriculture Organisation, some 97\% of Mozambique's farmed land is cultivated by small-holder farmers. They (and thus the food security of their families and communities) are hugely vulnerable to both flooding and drought, which seem to be becoming more extreme, very probably as a result of anthropogenic climate change (to which I shall return shortly).

Progress in tackling food security has been made on a small scale over several years through following the holistic, sustainable, methodologies of the 'Farming God's Way' approach. ${ }^{7}$ Communities have rapidly expanded what they have learned to new areas, and in 
the coming year there will be significant wider roll-out across the Diocese. Improved agricultural techniques include teaching about mulching (and so water conservation), and use of latrine compost. Another simple, but community transforming, initiative is the introduction of low wood burning clay stoves which are easy to make, and use a fraction of the fuel consumed by traditional ways. This both conserves trees and significantly reduces the time spent by women cutting and collecting wood, often at a distance from their homes, placing them at danger of assault. Thanks go particularly to: Tearfund (which has also trained Mozambicans in well-drilling); the Canadian government working with World Renew (the mission arm of the Christian Reformed Church in North America) $;^{8}$ and the Angola London Mozambique Association, ${ }^{9}$ among others.

Following sustained Anglican presence since the later 19th century, the Diocese of Niassa is one of the few bodies with long-term, deeply rooted, commitment among the communities of the region. Even the government's capacity remains limited and patchy. This has given the church a unique opportunity to support these communities with hope for every aspect of life, and even basic survival. Working amongst the poorest certainly means working with environmental issues, food security and family safety, into all of which the Spirit of God, given for all of creation, speaks of tangible possibilities of transformation, for lives and livelihoods, for environment and development.

The testimony of the Diocese is that these approaches, respecting the dignity and integrity of the local communities, have effectively delivered community development and improved agricultural outcomes in ways that are also the most beneficial to the surrounding environment. Further, such holistic mission has brought considerable and continuing church growth, with many conversions, and the planting of numerous new congregations. It was very humbling for me to spend some time in the Diocese in mid-2011, and see for myself how profoundly God is at work amongst such communities which seem so impoverished, not only materially, to the outsider. God's way is truly being demonstrated as the best way for human living.

\section{Bigger, harder, questions}

All we are doing in the Diocese of Niassa is now at risk from factors far beyond the control of the people of northern Mozambique. The effects of climate change will be very negative for these vulnerable communities. As the poorest people in one of the world's poorest countries, their voice is almost inaudible in decision-making that impacts radically upon 
them. Yet they are the ones who grasp in tangible ways what it means to live in partnership with creation.

The challenge somehow seems far more distant for those of us who take for granted electricity and clean water at the flick of a switch, the turn of a tap. Their source, production and supply take place so much removed from our daily lives that though we may have a mental comprehension of what is involved, it does not impact upon us in the way that fetching water and wood has on those for whom this is reality. I acknowledge, to my considerable shame (especially when I set my life beside members of my Province like those in Lesotho or Niassa), that so much of what I do in my attempt to be 'green' - from weedbusting in the Bishopscourt garden, to ending emails with a plea to 'consider the environment before printing', to planting a couple of olive trees now and again in response to my frequent overseas trips - is merely tinkering at the edges. In contrast, my unconsidered habits and daily practices generate an unjustly large and unsustainable carbon footprint, even before I get on an aeroplane for yet another global meeting, let alone the two hour flight to Johannesburg, which I take all too frequently along with so many others for whom it has become little different from catching a bus or train. For me, and, I suspect, for the majority of readers of Anvil, the impact of global warming and my personal contribution towards it, too often remain theoretical concepts rather than impinging upon us in concrete ways. I know that for as long as I, and the society of which I am a part, fail to change radically how we live, we are unlikely to have much impact upon those who can take the necessary decisions to ensure we do not destroy our planet.

This, then, is what poses the greatest challenge to my theology and my praxis. It is this that I shall consider in the rest of this article. For the recent history of South Africa has challenged Christians here to review radically our understanding of the role and voice of the church in the public space, in ways that also offer tools for addressing the challenges of safeguarding the integrity of creation.

\section{Living in the world}

In the bad old days, apartheid dominated everything. It was the lens through which the church viewed the world, and our vocation to follow God's mission and ministry within it. Tough though life was - at least, for the oppressed majority - it gave a certain clarity to issues of faith, current affairs, politics and so forth. For it was clear enough (to nearly all the churches) that apartheid was wholly wrong, nothing short of heresy, an affront to God and those created 
in his image, and was to be opposed. We might disagree on the best form of opposition, but the issue was clear cut.

With hindsight, we can see that this certainty brought a sort of comfortableness in our faith, which many have found disconcerting to lose in the radically different circumstances of democracy. Today we are not faced with one big overarching question, but many and varied challenges, from tackling poverty, unemployment and crime, through to balancing 'traditional' African social systems with internationally normative human rights. Rarely is there a simple solution evident to, and agreed by, all. Far too many issues are not only complex, but all possible responses seem to have advantages and disadvantages with consequences that are not wholly predictable. Further, Christians may often find themselves talking with a whole range of competing perspectives, all apparently having some biblical or theological justification. 'Welcome to the real world!' says a British friend who knows South Africa well, pointing out that what we now experience is the widely shared, longstanding, norm for most societies. Adjusting to this new context is calling out far more mature moral and ethical reflection, but beyond this it is also demanding of us a whole new understanding of public theology as the context for our reflection, and our consequential speaking and acting. For we had tended to look forward to apartheid's end as the answer to all our problems. Exaggerated expectations were further fuelled by unrealistic promises and inflated rhetoric from too many politicians, as democracy emerged. We did enjoy, thanks be to God, a peaceful transition from apartheid, but it did not rapidly deliver an affluent, easy, lifestyle for all, as so many had expected. In fact, economic transformation for those most disadvantaged by apartheid has had very limited impact, and is proving extremely difficult. This has come as a shock, even to people within the church, who fear that some moral or spiritual failing is the cause of us not reaching the promised nirvana.

What we need is a renewed theology, with concomitant praxis, of what it means to live in our new democratic context. We discover this as we explore living in the time between Christ's ascension and his return (this, interestingly, being what Augustine understood as 'the secular'). Wrestling to grasp what this fresh vocation focuses us on the tensions of living when the kingdom both is, and is yet to come. The answer is a particular sort of living with hope. This hope, I am convinced, is precisely what is required not only for our new political circumstances within South Africa, but also what Christians more widely need for our engagement with the big global questions of the environment and climate change. 


\section{Christian hope for a secular age}

The theologian whom I have found most helpful in exploring an adequate Christian response to our new context is Charles Mathewes, ${ }^{10}$ particularly as he writes in A Theology of Public Life. ${ }^{\text {a }}$ Here he seeks to define 'the public,' theologically, placing it within the allencompassing Christian narrative, rather than responding theologically to the 'givenness' of the place and time in which we find ourselves (the approach generally assumed by 'public theology'). Finding ourselves placed and oriented within God's outworking of salvation saves us from a number of pitfalls that have threatened South African Christians, and directs us to the authentically hope-filled pursuit of the gospel in mission and ministry, including in relation to environmental questions.

Being conscious that we are living 'during the world', as Mathewes terms it, means stepping back either from unrealisable expectations of God's kingdom being accomplished here and now (as, in effect, people thought would follow apartheid's collapse); or from resignedly concluding that nothing can be changed. It is not our task to bring in the fullness of God's reign; but nor should we accept the status quo. Neither is it all down to us, nor is there nothing we can do to make a difference. Rather, we, as individuals and the Church, are called into the obedient, faithful, persevering, life of discipleship by our Saviour and Lord. Responding to God in worship, we are drawn into his redemptive engagement with his creation, which unfolds with certainty, yet in ways beyond our ability fully to see or grasp. As Mathewes ${ }^{11}$ puts it 'Christ's saving work' - which of course encompasses all of creation 'has both always and not yet been completed'. Therefore 'during the world, we should live adventally, celebrating the inauguration of our redemption, in and through our participation in Christ's mission. The overall project of time is not yet concluded, and so we must undergo the historical process of salvation knowing that the consolations of redemption are not given to us immediately. Joy is not our imminent future; only the longing for joy is.' This is the perspective from which we engage with the public sphere around us.

Such engagement can therefore always be hopeful, in the truest sense of the world, for the source of our hope lies in Christ's redemption. It should both be grounded in, and be expressed out of, participation in a faithful worshipping, and most of all, Eucharistic,

\footnotetext{
a I am grateful to Stephen W. Martin for drawing attention to some of the links between Mathewes' work and the situation in South Africa, for example in his paper: Martin, S.W. (2012) The Anglican Church in Southern Africa and a Theology of Public Life. Theological Society of Southern Africa. University of KwaZulu-Natal, Pietermaritzburg, South Africa (June 2012).
} 
community. For it is at the Eucharist that we not only pray 'Your kingdom come' but 'we remember Christ's death and we proclaim his resurrection, even as we await his coming in glory. ${ }^{12}$ I find this hope more tangibly grounded in our current lives than, say, the more eschatologically framed hope of Jürgen Moltmann. Nonetheless, it still retains some of that 'is, and yet is still to come' provisionality. As Mathewes says, 'hope is always needed and always something we do not possess. It is a divine dynamic in which we may, through grace, participate, but which we try perpetually, in sin, to control., ${ }^{, 13}$

I find this understanding of hope very freeing. This provisionality allows us to participate within a messy and fallible world, without demanding that we 'get it completely right' in our goals, actions or achievements. It liberates us from being tossed between human optimism and pessimism as ultimate judgements on circumstances and events. We also need not fear being compromised through having to deal with flawed, sinful, political and economic systems. I was not surprised to learn that Mathewes is an Episcopalian, since his approach seems so much to echo the example of Christ's incarnation, said to be so beloved of Anglicans, and which I certainly have found a touchstone for my own ministry. ${ }^{14}$ Jesus in his kenosis 'does not know the day or the hour' yet serves the Father's will. All we need to do is the 'next thing' that God puts before us, living in response to his Spirit at work within us. It seems to me that God's assurance is that whenever we are thus caught up into gospel-shaped engagement, whatever we do will indeed bear 'fruit that will last'(John 15:16) even if we cannot immediately see it ourselves. But from the eschatological perspective, we can be confident that faithful obedient lives (practising ascesis, to use Mathewes' term) will have eternal significance.

Such hope prompts active engagement. To quote Mathewes once again, 'Hope is not only provisional but pro-vocative, in two senses. First of all, hope provokes action. It is not simply an inner state. No one who is hopeful can resist participating in the hopeful world that has been disclosed to them. Second, the action hope so provoked is fundamentally vocative, linguistic and even evangelical, expressing thanks to the hopeful world and seeking to lead others to appreciate that hope as well. ${ }^{15}$

\section{Living hopefully in a demoralising world}

How does such hope translate into practical action? A major first step within Southern, and especially South, Africa is educating Christians to view in such terms their vocation to the life of 'faithful worship, witness and service', of which our confirmation service speaks. We 
must help God's people find a fresh confidence that their ultimate reality lies in being held by God's unfolding salvation within this time of tension 'during the world'. It seems to me that this confidence may also need to be rediscovered in other parts of the world, where Christianity's traditional standing and engagement within the public space has weakened with growing secularism and multiculturalism.

Finding our place in God's greater story - and realising that what we do and see is not, and does not need to be, the whole picture - is vital if, in the face of such demoralising circumstances around us, we are to be able to follow St Paul's exhortation 'Let us not grow weary in doing what is right, for we will reap at harvest time, if we do not give up' (Gal. 6:9). We are also then able not to despise the small actions which we are able to take - even as we recognise we must do more and better. So we will persevere with replacing light-bulbs and shower-heads; turning off phone chargers and appliances on stand-by; recycling; switching to green cleaning materials and garden pesticides; lagging geysers and buildings; cutting back transport; planting trees, and so on and so forth.

We will also work with hope for more fundamental change, and again first within the Church. The Anglican Church of Southern Africa instituted a 'Season of Creation' in 2008, issuing resources both for educating our parishes through small group work, and for liturgical use in services, with five weeks of themes. A second booklet with new and updated material was issued earlier in 2012. Parishes are encouraged to use them annually, usually in the weeks up to St Francis' Day, 4 October. We have also appointed a Provincial environmental coordinator, full time from 2013, with seed funding from the Archbishop of Canterbury.

Further, when in 2010 we launched a Provincial Vision to run through to 2020, the environment was identified as a priority, for both further theological work and action of various sorts. Much of this is pursued ecumenically and with other faith communities, as outlined in the article on the Southern African Faith Communities Environment Institute, with its distinctive approach of encouraging resources tailored to the particularities of each religious tradition. ${ }^{16}$

Bringing the environment consciously into the worshipping life of the church, and particularly its Eucharistic life, is vitally important in terms of integrating God's message of hope with the more than challenging realities we face, particularly the continuing failure of the global community to respond adequately. Anglican faith and theology is often described in terms of lex orandi, lex credendi, that our prayers shape our beliefs and praxis. I suspect that it is only when the theme of safeguarding God's creation becomes wholly intrinsic to our 
liturgical life, that we will find it properly reflected in our behaviour in ways that go far beyond the 'tinkering at the edges' to which I referred to earlier. Both Lambeth 2008, and 2012's Anglican Consultative Council meeting, rightly place a high priority on incorporating the environment into our liturgical life, alongside other tasks of education, advocacy and empowerment for action. I would put it more strongly: liturgy provides the best foundation for building in other areas.

Our ultimate goal must be to change the dominant narrative around environmental issues, and we can only expect the world to change if we change first. I am reminded of how the Church of England, at least in some quarters, was initially slow to reject slavery, sharing in the vested interests for whom this was seen as very bad for business. But ultimately the generally accepted narrative changed, and slavery ended. More recently, it was the weight of public opinion that shifted global governments and financial institutions in ways that were, at least initially and superficially, seen as 'bad for business' over both Jubilee 2000 and Make Poverty History.

The 1978 Lambeth Conference was more perceptive than perhaps was realised at the time, in continuing Resolution 1 (quoted above): 'such changes will not be easy to make and will require wise leadership from both secular and religious sources. Creative solutions will require both technical knowledge and moral insights. Decisions will be not only difficult but unpopular.' Only when public opinion shifts will governments grasp difficult nettles. Churches must strive to shape that opinion, drawing people into discourse that puts people and planet before power and profits; expounding philosophies of 'enough' which reflect the realities of a finite planet with finite resources, and the need for these to be used fairly, rather than the groundless and dangerous assumptions of limitless growth and consumption. (My predecessor as convenor of the Anglican Communion Environmental Network, Bishop George Browning, of the Anglican Church of Australia has written a series of excellent studies exploring the roots and meaning of Sabbath and how a fresh understanding and practice of this biblical concept can reconnect economics to ethics, and shape human society in a manner that is consistent with the creation upon which it depends). ${ }^{17}$ We cannot let 'business as usual' be the substantive response to the continuing economic crises.

Finally, let me end with another important lesson of living, and speaking, hopefully. Behavioural science tells us that whenever a positive vision is central, it becomes the touchstone that shapes our words, actions and policy-making, and the magnet that draws us forward. If we always focus on problems, we lose sight of where we are going, and get 
dragged down. St Paul knew the force of this two millennia ago, when he wrote to the Philippians 'Whatever is true, whatever is honourable, whatever is just, whatever is pure, whatever is pleasing, whatever is commendable, if there is any excellence and if there is anything worthy of praise, think about these things' - or, as another translation puts it, 'let your mind dwell on these things' (Phil. 4:8). Having taken a conscious decision to frame my preaching and public speaking in these more positive terms in the last few months, I have been more than pleasantly surprised at how great the impact has been. Not least, I have found within and beyond the church a deep hunger to hear the reassurance of genuine hope, founded in God, and this too is a source of encouragement.

Brothers and sisters in Christ, we do indeed live 'during the world', and as we know, death is at work all around us - but the power of God for redemption among us is greater.

'Therefore', let us say with St Paul, 'my beloved, be steadfast, immovable, always excelling in the work of the Lord, because you know that in the Lord your labour is not in vain'. ${ }^{\text {b }}$

\section{Biography}

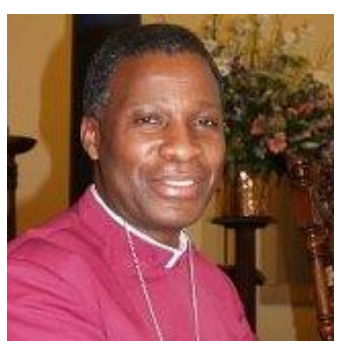

The Most Revd Dr Thabo Makgoba has been Archbishop of Cape Town and head of the Anglican Church of Southern Africa since the beginning of 2008. He served on the Design Group for the 2008 Lambeth Conference, is a member of the Anglican Consultative Council, and chairs the Anglican Communion Environmental Network. He has a $\mathrm{PhD}$ from the University of Cape Town in work-place spirituality.

\footnotetext{
${ }^{\mathrm{b}}$ I am grateful to my Researcher, the Revd Canon Dr Sarah Rowland Jones, for her contribution to this article, and to my thinking around this subject.
} 


\section{References}

${ }^{1}$ ACNS staff (2012, November 1). Bishop Qiliho: The 'reality of climate change' is being considered all across the Communion. Podcast retrieved December 29, 2012, from http://www.aco.org/acns/news.cfm/2012/11/1/ACNS5228

${ }^{2}$ The Lambeth Conference Official Website (2012). Lambeth Conference Resolutions Archive. Retrieved December 29, 2012, from http://www.lambethconference.org/resolutions/index.cfm ${ }^{3}$ Anglican Consultative Council (2012). Anglican Consultative Council Resolutions. Retrieved December 29, 2012, from http://www.anglicancommunion.org/communion/acc ${ }^{4}$ Anglican Communion (1999). Mission - The Five Marks of Mission. Retrieved December 29, 2012, from http://www.anglicancommunion.org/ministry/mission/fivemarks.cfm ${ }^{5}$ The Lambeth Conference Official Website (2008). Lambeth Indaba. Capturing Conversations and Reflections from the Lambeth Conference 2008. Equipping Bishops for Mission and Strengthening Anglican Identity (2008). Paragraphs $60 \& 62$. Retrieved December 29, 2012, from http://www.lambethconference.org/resolutions/2008/ ${ }^{6}$ Tearfund (2012, August 8). Umoja. Retrieved December 29, 2012, from http://tilz.tearfund.org/Churches/Umoja/ ${ }^{7}$ Farming God's Way (2012). Retrieved December 29, 2012, from http://www.farminggods-way.org/

${ }^{8}$ World Renew (2012). Malawi. Retrieved December 29, 2012, from http://worldrenew.net/malawi

${ }^{9}$ Angola, London and Mozambique Association (ALMA) (2012). Retrieved December 29, 2012, from http://www.almalink.org/

${ }^{10}$ Mathewes, C. (2007). A Theology of Public Life. Cambridge: Cambridge University Press.

${ }^{11}$ Mathewes, C. (2007). Ibid. p. 33.

${ }^{12}$ Mathewes, C. (2007). Ibid. p. 40.

${ }^{13}$ Mathewes, C. (2007). Ibid. p.214

${ }^{14}$ Makgoba, T. (2009). Politics and the Church - Acting incarnationally. Journal of Anglican Studies 7, 87-91.

${ }^{15}$ Mathewes, C. (2007). Op. cit. p.247.

${ }^{16}$ Davies, G. (2013). SAFCEI (Southern African Faith Communities' Environment Institute). Anvil 29(1), 87-91. DOI: 10.2478/anv-2013-0007 
Thabo Makgoba- Hope, the Environment and the Majority World

${ }^{17}$ Anglican Communion Environmental Network (ACEN) (2012). Retrieved December 29, 2012, from http://acen.anglicancommunion.org/index.cfm 